\title{
TREE SHADE PREFERRED BY RECREATIONAL USERS OF A BRAZILIAN BEACH SIDEWALK
}

\author{
by U.C. Malavasi ${ }^{1}$ and M.M. Malavasi ${ }^{1}$
}

\begin{abstract}
Barbecuing near the beach is a well-established leisure activity during weekends and holidays for many people in the state of Rio de Janeiro, Brazil. A daily nonstimulated census composed of personal interviews conducted along the beach of Mangaratiba was undertaken during school vacations in summer (January and February) and winter (July) of 1994 and 1995. A total of 955 interviews were completed. On average, each group of barbecuers consisted of 3 adults and 2 children (up to 12 years old). Ninety-five percent of the barbecues took place on weekends and holidays. The responses suggested that $85 \%$ of the groups prefer to be under shade trees, even during the winter months. Reasons offered for this preference are temperature amelioration $(80 \%)$, privacy $(65 \%)$, security (45\%), and isolation (30\%). On average, a barbecue lasts 6.1 hours.
\end{abstract} Janeiro.

Key Words. Beach barbecue; shade preference; Rio de

Forests have great amenity value in an industrialized and urbanized society. A landscape ornamented with forests and landscape elements is considered an important indicator of the quality of life. Kaplan and Kaplan (1989) have formulated a theory on the interaction between people's attention and their surroundings. The new urban living-with fast vehicles, flashing neon signs, and strong colorscauses constant stress. Research indicates that vegetation and nature allow our sensory apparatus to relax us and infuse us with fresh energy. Visits to green areas bring relaxation and sharpen our concentration because we need to use only our spontaneous attention. At the same time, we get fresh air and sunlight, which have significance for human diurnal and annual rhythms (Kaplan and Kaplan 1989). Similarly, it has been shown that hospitalized patients recovered faster when they had a view of trees through a window (Moll and Ebenreck 1989).

Unfortunately, uninformed citizens, including city council members, too often think only of the aesthetic value of trees in urban settings. Urban forestry research in the past has centered on the value of street and yard trees to urban inhabitants. Certainly on a local scale, street and yard trees have many direct effects on the quality of life of urban inhabitants (Moll and Ebenreck 1989). The value of wilderness to human society increases with urbanization and as a result urban and suburban inhabitants desire contact with nature. This desire manifests itself in an increased demand for urban trees and woodland amenities as society seeks to enhance the quality of life in cities (Miller and Miller 1991).

The use of forests for recreational purposes is an outcome of the modern way of life. The link between nature and everyday life has vanished during modern times. To become aware of this link, people in modern societies need opportunities for outdoor recreation.

Mangaratiba beach, a southern district along the Rio de Janeiro coast line, bears a single line of beach trees (Hibiscus pernambucensis and Terminalia catappa) along its sidewalk. This beach is used mainly for weekend barbecues (Malavasi 1997). To quantify the relationship between city dwellers and urban trees, a study on the public awareness and uses of urban trees of Mangaratiba beach was conducted. This beach is visited mainly by the middleto-low income families living in Duque de Caxias, Nova Iguaçu, and Nilópolis counties.

\section{MATERIALS AND METHODS}

A daily nonstimulated census covering all the groups that used the beachfront for barbecues (generally using a small, charcoal-energized, metal-framed device) was taken during January, February, and July 1994 and 1995. Weekdays were covered from 9:00 A.M. to 2:00 P.M., and weekend days from 8:00 A.M. to 3:00 P.M. Information was collected informally and included the number of persons in the group, gender, age, school level, time spent on the beach, choice of place for barbecuing, and reason for the choice. In addition, the interviewer would ask about waste disposal and leftovers at the end of the barbecue. Responses were recorded on a notepad after- 
wards. The interview was undertaken within the initial 30 to 60 minutes upon a group's arrival at the beach. If requested, the interviewer explained that the data were part of a family/group comportment study by university students without any political and/or government implications.

\section{RESULTS AND DISCUSSION}

Barbecuing near the beach is a well-established leisure activity during weekends and holidays for many people in the state of Rio de Janeiro, Brazil. Recent economic constraints have pressed entire families to use parks, beaches, or recreational areas near urban centers instead of traveling to distant places for recreation. Several family groups from as far as $60 \mathrm{~km}$ (37 mi) from the beach of Mangaratiba reported spending 1 day per weekend at the beach barbecuing and relaxing.

We conducted 457 interviews in 1994 and 498 in 1995. Ninety percent of the groups interviewed were summer users (January and February) in both years. This trend is explained by the fact that although mean winter temperatures in the state (average $21^{\circ} \mathrm{C}$ $\left.\left[70^{\circ} \mathrm{F}\right]\right)$ are warm, most beach users avoid winter months. Groups consisted mainly of a single family with relatives and neighbors. On average, the number of members in a group was 3 adults and 2 children (up to 12 years old). Females comprised $40 \%$ to $65 \%$ of the group members.

Mangaratiba beach is $4.1 \mathrm{~km}(2.5 \mathrm{mi})$ long and 20 to $30 \mathrm{~m}$ ( 65 to $100 \mathrm{ft}$ ) wide. It is a well-protected bay with very calm sea water. Close to the cemented sidewalk, specimens of Hibiscus pernambucensis and Terminalia catappa were planted 10 to 15 years ago, spaced at regular intervals of 10 to $15 \mathrm{~m}$ (33 to $50 \mathrm{ft}$ ).

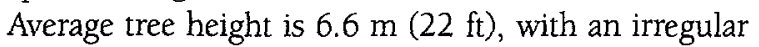
crown form that offers deep shade within a radius of $3.5 \mathrm{~m}$ ( $11 \mathrm{ft}$ ) from the trunk of most trees. Consequently, there are a large number of possible niches in which to set up barbecue equipment. Eighty-five percent of the groups interviewed preferred to set their equipment in the shaded spots rather than in the sunny spots. Reasons for those choices are listed in Table 1. Although shade was the most important reason for site selection, other factors considered important were privacy and isolation.

Expected time for barbecues varied from 3 to 7 hours, with an average of 6.1 hours. However, much
Table 1. Reasons for choice of barbecue spot on Mangaratiba beach.

\begin{tabular}{ll}
\hline Reasons & Percentages \\
\hline Temperature amelioration & 80 \\
Privacy of the party & 65 \\
Security & 45 \\
Isolation & 30 \\
Protection & 24 \\
Comfort & 19 \\
\hline
\end{tabular}

of that time ( $40 \%$ to $50 \%$ ) is used to set up and to start the charcoal fire (inferred by direct observation). In addition, $60 \%$ of the interviewed groups could not predict the length of their stay because of the frequent unfavorable weather during summer months (afternoon tropical showers).

\section{CONCLUSIONS}

The increased interest in urban environmental problems will probably mean a considerable increase in parks and green areas over the coming decades. Most of these will be laid out in the larger cities of Asia, Africa, and Latin America. Over the coming years, the main challenge will be to ensure that the expansion of green infrastructure in the world's urban areas is implemented within the framework of sustainable development, without the use of technology inimical to man and nature. As parks and green areas are developed, it is vital that we consider the needs of the people who visit them. Trees in green areas provide communitywide ecological benefits, but they also provide social benefits to those who visit these areas for recreation.

\section{LITERATURE CITED}

Kaplan, R., and S. Kaplan.1989. The Experience of Nature. Cambridge University Press, Cambridge, England. 340 pp.

Malavasi, U.C. 1997. Perspectivas para o futuro da arborização urbana, pp 133-141. In Andrade, J.A. (Ed). Anais I Simpósio sobre Arborização Urbana do Rio de Janeiro. UFRJ, Rio de Janeiro.

Miller, R.H., and R.W. Miller.1991. Planting survival of selected street tree taxa. J. Arboric. 17(7):185-191.

Moll, G., and S. Ebenreck. 1989. Shading Our Cities: A Resource Guide for Urban and Community Forests. Island Press, Washington, DC. 333 pp. 


\section{${ }^{1}$ Professor}

Dept. Agronomia

UNIOESTE

\section{Mal. Câdido Rondon}

\section{Paraná, Brazil}

Résumé. Les activités autour d'un barbecue durant les fins de semaine près d'une plage font partie du mode de vie habituel durant les fins de semaine et les périodes de vacances pour une part importante de la population de Rio de Janeiro au Brésil. Un recensement sur le tas à partir d'interviews individuels de gens le long de la plage de Mangaratiba a été effectué durant les vacances scolaires d'hiver et d'été de 1994 et 1995. En général, chaque groupe autour d'un barbecue comptait trois adultes et deux enfants de 12 ans ou moins. Les réponses recueillies indiquaient que $85 \%$ des groupes preféraient installer leur barbecue à l'ombre d'un arbre, même en hiver. Les motifs énoncés pour justifier ce choix étaient: température plus supportable $(80 \%)$, intimité $(65 \%)$, sécurité $(45 \%)$ et isolement $(30 \%)$. En général, un barbecue durait 6,1 heures.

Zusammenfassung. Das urbane Umfeld hat bedeutende soziale, wie auch umweltrelevante Vorteile. Unter den erstgenannten sind die Vorteile für Freizeitgestaltung meist durch Professionelle behindert. So sind WochenendGrillfeste an Wochenenden und während der Ferien am Strand sehr etablierte Freizeitbeschäftigungen für einen großen Teil der Bevölkerung von Rio de Janeiro, Brasilien.
So wurden während des Sommers (Januar und Februar) und während der Winterferien (Juli) 1994 und 1995 täglich Erhebungen durch Interviews durchgeführt. Insgesamt waren 955 Interviews erfolgreich. Durchschnittlich setzt sich jede Grillgruppe während der Wochenenden und in den Ferien, wo nahezu $95 \%$ aller Gruppen da sind, aus 3 Erwachsenen und 2 Kindern bis zu 12 Jahren zusammen. Die Antworten zeigten, daß $85 \%$ der Gruppen bevorzugen, sich zum Picknick während der Wintermonate unter Schattenbäume zu setzen. Die genannten Gründe für diese Wahl waren: Temperaturanpassung (80\%), Intimität $(65$ $\%)$, Sicherheit (45\%) und Abgeschiedenheit (30\%). Durchschnittlich dauert jedes Picknick 6,1 Stunden.

Resumen. El asado de fin de semana cerca de la playa es un modo bien establecido de pasar el tiempo libre durante fines de semana y vacaciones para una gran población del estado de Río de Janeiro, Brasil. Un censo diario no estimulado compuesto de entrevistas personales a lo largo de la playa de Mangaratiba fue conducido durante el verano y en las vacaciones escolares de invierno de 1994 y 1995. En promedio, cada grupo de personas con asado está compuesto de 3 adultos y 2 niños (arriba de los 12 años de edad). Las respuestas sugirieron que el $85 \%$ de los grupos prefieren establecer su asado bajo cualquier sombra de árbol, incluso durante los meses de invierno. Las razones ofrecidas para la elección anterior son: mejoramiento de la temperatura $(80 \%)$, privacía $(65 \%)$, seguridad (45\%) y aislamiento $(30 \%)$. En promedio, el asado dura 6.1 horas. 